\title{
PENERAPAN MODEL PEMBELAJARAN KOOPERATIF TIPE TEAM ASSISSTED INDIVIDUALIZATION (TAI) MELALUI SUPERVISI KLINIS UNTUK MENINGKATKAN KEMAMPUAN GURU DALAM MELAKSANAKAN PROSES PEMBELAJARAN YANG INOVATIF
}

\author{
Ni Wayan Nuriati \\ Pengawas UPT Sukawati \\ email : nuriatinw@gmail.com
}

\begin{abstract}
Abstrak
Penelitian Tindakan Sekolah yang dilakukan ini bertujuan untuk meningkatkan kemampuan guru dalam melaksanakan proses pembelajaran yang inovatif di SD Negeri 6 Batubulan pada semester II tahun pelajaran 2017/2018 dengan penerapan model pembelajaran tipe team assissted individualization (TAl)melalui supervisi klinis. Data hasil penelitian ini dikumpulkan dengan cara melakukan supevisi dengan instrumen. Dalam menganalisis data yang diperoleh digunakan metode analisis deskriptif. Data yang dihasilkan dari penelitian ini terdiri dari data awal, data siklus I dan data Siklus II. Dari data awal diperoleh rata-rata kemampuan melaksanakan proses pembelajaran yang inovatif, hanya mencapai nilai 75,14 dan ketuntasan baru mencapai $35,71 \%$. Data ini jauh di bawah harapan mengingat ketuntasan pelaksanaan proses pembelajaran minimal 80,00 . Rata-rata nilai siklus I sudah terjadi peningkatan yaitu rata-ratanya mencapai 78,85 dan prosentase ketuntasannya mencapai $42,85 \%$. Pada siklus II perolehan rata-ratanya sudah mencapai 88,71 dan persentase ketuntasan sudah mencapai $100 \%$. Data pada Siklus II ini sudah sesuai harapan, yaitu kemampuan guru dalam melaksanakan proses pembelajaran yang inovatif di SD Negeri 6 Batubulan pada semester II tahun pelajaran 2017/2018 mengalami peningkatan dengan penerapan model pembelajaran Kooperatif Tipe Team Assissted Individualization (TAI)melalui supervisi klinis.
\end{abstract}

Kata kunci: Pembelajara Kooperatif Tipe Team Assissted Individualization (TAl), Supervisi Klinis, Kemampuan Guru

\begin{abstract}
School Action Research conducted aims to improve the ability of teachers to carry out innovative learning processes in SD 6 Batubulan in the second semester of the 2017/2018 school year with the application of team-type assissted individualization learning models (TAI)through clinical supervision. Data from the results of this study were collected by revising with instruments. In analyzing the data obtained used descriptive analysis method. The data generated from this study consisted of preliminary data, first cycle data and Cycle II data. From the initial data obtained the average ability to carry out innovative learning processes, only reached the value of 75.14 and completeness only reached $35.71 \%$. This data is far below expectations given the completeness of the implementation of the learning process of at least 80.00 . The average value of the first cycle has increased namely the average reached 78.85 and the percentage of completeness reached $42.85 \%$. In the second cycle the acquisition has reached 88.71 and the percentage of completeness has reached 100\%. Data in Cycle II has been in line with expectations, namely the ability of teachers to carry out innovative learning processes in Batubulan Public Elementary School 6 in the second semester of 2017/2018 school year has increased with the application of Team Assisted Individualization Cooperative learning models (TAI)through clinical supervision.
\end{abstract}

Keywords: Team Assissted Individualization Cooperative Learning (TAI), Clinical Supervision, Teacher Ability 


\section{Pendahuluan}

Ketidak berhasilan perbaikan mutu pendidikan telah membuat para pendidik cukup tercengang, hal ini membuat kita setuju terhadap pencanangan Departemen Pendidikan Nasional, tentang Managemen Peningkatan Mutu Pendidikan. Di sini peningkatan mutu pendidikan diarahkan kepada menggali kemampuan yang ada di sekolah. Berbeda dengan gaya yang terdahulu di mana pendidikan itu orientasinya pada input (input oriented). Yang tertera dalam input oriented misalnya: penyediaan buku-buku dan alat belajar lainnya, penyediaan sarana pendidikan, pelatihan guru dan tenaga kependidikan yang lain. Dengan ini terpenuhi maka diharapkan memperoleh output yang bermutu. Dengan pencanangan manajemen peningkatan mutu yang telah dipaparkan, maka sekolah akan menjadi pusat untuk bisa mutu pendidikan itu meningkat. Peningkatan mutu pendidikan sudah pasti banyak ditentukan oleh mutu guru dalam banyak hal. Secara khusus dalam penelitian ini dibahas peningkatan mutu guru dalam melakukan inovasinya proses pembelajaran, kemampuan melaksanakan penilaian, kemampuan melaksanakan evaluasi dan kemampuan guru dalam melaksanakan tindak lanjut terhadap proses pembelajaran yang telah dilakukan. Menurut UKTI (2015) Pendidikan merupakan sarana terpenuhinya proses belajar manusia. Tanpa pendidikan manusia tidak mampu mengembangkan fitrahnya sebagai insan pedagogik yang perlu dididik dan mendidik. Namun, suatu pendidikan akan mempunyai mutu yang tinggi apabila guru mempunyai mutu yang tinggi pula. Sedangkan mutu guru sangat ditentukan oleh pemahamannya tentang komponen, pendekatan, dan berbagai metode pengajaran yang diterapkan dalam proses pembelajaran. Usaha-usaha guru dalam mengatur dan menggunakan berbagai variabel pengajaran merupakan bagian penting dalam keberhasilan siswa mencapai tujuan yang direncanakan. Menurut Achdiyat (2016) untuk mencapai keberhasilan suatu pendidikan maka dibutuhkan kesadaran dari peserta didik untuk mau belajar kemudian didukung oleh tenaga pengajar yang kompeten sehingga dapat tercipta suasana belajar yang kondusif. Apabila suasana belajar kondusif maka keberhasilan proses belajar mengajar akan dapat tercapai sehingga potensi yang ada pada peserta didik dapat dikembangkan. Dengan demikian maka peserta didik akan memiliki kemampuan, pengendalian diri, kepribadian yang baik, kecerdasan, perilaku serta keterampilan yang diperlukan dirinya, masyarakat, bangsa, dan negara.

Pembelajaran di sekolah akan sangat efektif apabila guru melaksanakannya dengan memahami peran, fungsi dan kegunaan mata pelajaran yang diajarnya. Di samping pemahaman akan hal-hal tersebut keefektipan itu juga ditentukan oleh kemampuan guru untuk merubah paradigma pengajaran menjadi pembelajaran. Menurut Megawati (2012) Model pembelajaran merupakan salah satu faktor eksternal yang mempengaruhi hasil belajar siswa. Model pembelajaran adalah salah satu cara yang dipergunakan guru dalam menyampaikan materi kepada siswa dengan maksud untuk mencapai tujuan belajar yang disepakati. Model pembelajaran juga dapat memacu proses pembelajaran untuk selalu menerapkan pengajaran antara guru dengan siswa secara dua arah, tidak hanya dari guru kepada siswa saja.

Beberapa model pembelajaran terbaru harus diupayakan guru demi berhasilnya pengembangan intelektual, sosial dan emosional yang akan berperan sebagai kunci penentu menuju keberhasilan peningkatan hasil belajar. Fungsi mata pelajaran yang diampu perlu untuk dipahami oleh pengawas untuk mempersiapkan guru mampu merefleksikan pengalamannya sendiri, pengalaman orang lain, mengungkapkan gagasan-gagasan dan perasaan serta memahami beragam nuansa makna. Di samping mengetahui peran, fungsi dan kegunaan mata pelajaran yang diampu, sebagai seorang guru juga diperlukan untuk mampu menerapkan beberapa alur dan metode ajar sehingga paradigma pengajaran dapat dirubah menjadi paradigma pembelajaran.

Kelemahan-kelemahan di lapangan selama proses pembelajran yang dilakukan di SD Negeri 6 Batubulan pada semester II tahun pelajaran 2017/2018 yang menyebabkan rendahnya kemampuan guru dalam melaksanakan proses pembelajaran yang inovatif, tidak sepenuhnya disebabkan oleh faktor luar seperti kesibukan guru, keadaan rumah tangga, 
lingkungan dan lain-lain. Kelemahan-kelemahan yang ada banyak pula dipengaruhi oleh faktor dari dalam guru itu sendiri seperti kemauan menyiapkan bahan yang lebih baik, kemauan menyiapkan media-media pembelajaran yang menarik.

Semua uraian di atas menunjukkan hal-hal yang perlu dilakukan dalam upaya meningkatkan kemampuan guru melaksanakan proses pembelajaran mengikuti alur model pembelajaran kooperatif Tipe Team Assissted Individualization (TAI) melalui supervisi klinis. Apabila betul-betul guru menguasai dan mengerti tentang hal-hal tersebut dapat diyakini bahwa kemampuan guru dalam proses pembelajaran bisa ditingkatkan. Namun kenyataannya kemampuan guru dalam melaksanakan proses pembelajaran yang inovatif di SD Negeri 6 Batubulan hanya mencapai rata-rata 75,14 dengan kualifikasi $C$ (cukup) yaitu ketuntasan guru hanya mencapai $35,71 \%$. Hal ini sangat jauh dari indikator keberhasilan yang mengharapkan kualifikasi A (amat baik) dengan rentang nilai dari 86-100.

Melihat kesenjangan antara harapan-harapan yang telah disampaikan dengan kenyataan lapangan sangat jauh berbeda, dalam upaya memperbaiki mutu pendidikan sangat perlu kiranya dilakukan perbaikan cara pembelajaran. Salah satunya adalah perbaikan pembelajaran dengan, Supervisi klinis dengan menggunakan alur pembelajaran Kooperatif Tipe Team Assissted Individualization (TAI) Sebagai upaya untuk meningkatkan kemampuan guru dalam melaksanakan proses pembelajaran yang inovatif. Oleh karenanya penelitian ini sangat penting untuk dilaksanakan. Menurut Tama (2017) Model pembelajaran kooperatif metode Team Assisted Individualization merupakan bentuk model pembelajaran yang dapat melatih siswa berpikir kreatif, kritis, dan efektif. Selain itu, metode Team Assisted Individualization dibuat untuk memanfaatkan keuntungan potensi siswa dalam bersosialisasi yang baik dari model pembelajaran kooperatif. Dengan menerapkan model pembelajaran kooperatif metode Team Assisted Individualization para siswa diharapkan akan termotivasi dalam pelajaran matematika, siswa akan saling mengecek pekerjaan satu sama lain.

Rumusan masalah dalam penelitian ini terurai sebagai beriku: Apakah penerapan model pembelajaran Kooperatif Tipe Team Assissted Individualization (TAI) melalui supervisi klinis mampu meningkatkan kemampuan guru dalam dalam melaksanakan proses pembelajaran yang inovatif di SD Negeri 6 Batubulan pada semester II tahun pelajaran 2017/2018? Tujuan penelitian ini adalah Untuk meningkatkan kemampuan guru dalam dalam melaksanakan proses pembelajaran yang inovatif di SD Negeri 6 Batubulan pada semester II tahun pelajaran 2017/2018 dengan menerapkan model pembelajaran kooperatif Tipe Team Assissted Individualization (TAI) melalui supervisi klinis.

Manfaat hasil penelitian secara teoritis sebagai acuan dalam memperkaya teori dalam rangka peningkatan kompetensi guru. Sedangkan secara praktis penelitian ini diharapkan bermanfaat: 1) bagi siswa, akan mengenal model pembelajaran baru; 2) bagi guru, akan mampu melaksanakan model pembelajaran Kooperatif Tipe Team Assissted Individualization (TAl); 3) bagi sekolah, sebagai pegangan penanggulangan kwalitas pembelajaran dan 4) bagi pendidik secara umum akan dapat dipakai sebagai pegangan untuk meningkatkan prestasi belajar.

\section{Metode}

Penelitian yang dilakukan di SD Negeri 6 Batubulan di harapkan mampu meningkatkan kemampuan gugu-guru dalam pelaksanaan proses pembelajaran. Penelitian tindakan ini terfokus pada penelitian tindakan sekolah. Untuk penelitian ini penulis memilih rancangan penelitian tindakan yang disampaikan oleh Dave Ebbut seperti terlihat pada gambar berikut: 


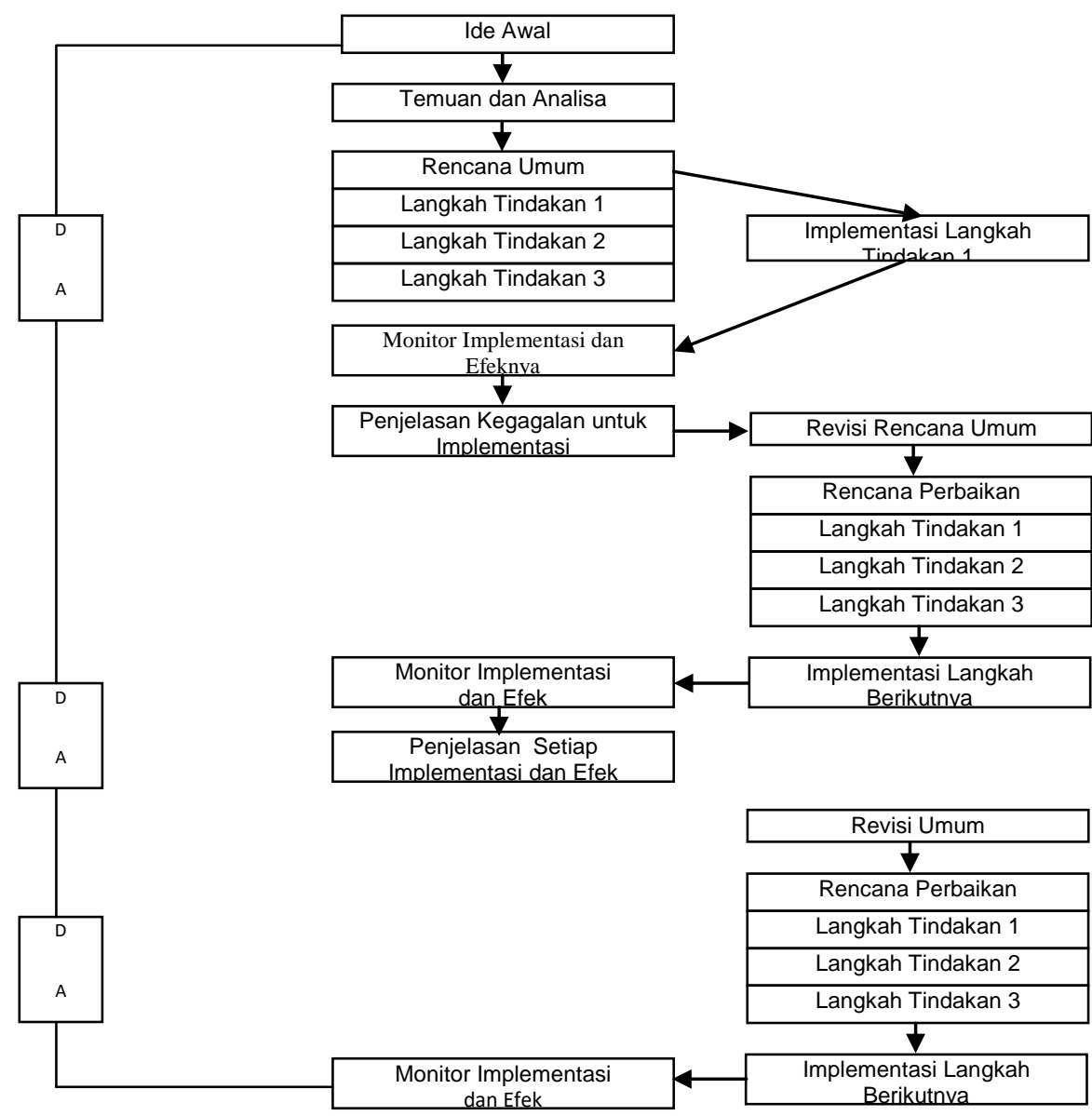

Prosedur:

Gambar 1. Rancangan Penelitian Tindakan Model Ebbut (1985)

Sebagai alur PTK, Ebbut memberi contoh sebagai berikut.

Pada daur I dimulai dengan adanya ide awal akibat temuan dan analisis yang telah dilakukan. Setelah ada temuan tersebut dibuatlah perencanaan umum sesuai langkah yang direncanakan baik tindakan 1, tindakan 2 maupun tindakan 3. Sesudah membuat perencanaan, diimplementasikan dalam tingkat 1 , dimonitoring implementasinya serta efeknya kemudian dijelaskan kegagalan-kegagalan yang ada selama implementasinya lalu dibuat revisi umum untuk perencanaan tindakan selanjutnya.

Pada tindakan selanjutnya, perencanaan yang telah dibuat diimplementasikan, terus dimonitor implementasinya serta efek yang ada, dijelaskan setiap langkah implementasinya dan efeknya. Setelah mengetahui bagaimana hasil dan efeknya, dibuat lagi perencanaan untuk tindakan selanjutnya. Demikian berlanjut sampai menemukan hasil yang sesuai tujuan yang direncanakan.

Subjek penelitian ini adalah guru-guru di SD Negeri 6 Batubulan dalam pelaksanaan proses pembelajaran semester II tahun pelajaran 2017/2018. Objek Penelitian ini adalah peningkatan kemampuan guru-guru dalam melaksanakan proses pembelajaran yang inovatif dengan menggunakan model pembelajaran Kooperatif Tipe Team Assissted Individualization (TAI) melalui supervisi klinis.

Penelitian tindakan sekolah yang dilakukan ini sudah sudah terjadwal sedemikian rupa yaitu dari bulan Januari sampai bulan Juni pada semester II tahun pelajaran 2017/2018. Kegiatannya termasuk perencanaan/pembuatan proposal pelaksanaan, observasi/pengambilan data dan refleksi.

Metode mengumpulkan data adalah observasi. Observasi adalah suatu teknik atau cara mengumpulkan data dengan jalan mengadakan pengamatan terhadap kegiatan yang sedang 
berlangsung, kegiatan tersebut bisa memberikan pengarahan, personil bidang kepegawaian yang sedang rapat, dsb (Sukmadinata, 2007: 220). Setelah kegiatan supervisi individual ini berlangsung dilakukan kegiatan supervisi seperti: diksusi, tanya jawab, unjuk kerja dan bersama-sama melakukan studi dokumen terhadap buku-buku pegangan guru. Hasil tanya jawab tidak dipaparkan karena hal tersebut merupakan langkah untuk memperkuat kemampuan guru-guru melaksanakan proses pembelajaran untuk menopang kegiatan nyata yang dilakukan. Unjuk kerja dilakukan dengan melakukan proses pembelajaran setelah mereka siap dengan perencanaan yang telah dibuat. Demikian rencana pengumpulan data yang penulis susun. Adapun data hasil penelitian ini yang dipergunakan dalam menganalisis adalah analisis deskriptif. Untuk menganalisis data hasil penelitian ini digunakan model analisis kuantitatif. Ini dilakukan karena data yang diperoleh berupa angka. Cara analisis yang direncanakan adalah mencari mean, median, modus, , interval kelas, penyajian dalam bentuk tabel dan grafik. Yang penulis rencanakan ini hanya sebatas perhitungan yang gampang pada tingkat statistika dasar.

Instrumen dari penelitian ini adalah lembar observasi yang ada di masing-masing RPP. Indikator keberhasilan dari penelitian ini diusulkan pada siklus I dan siklus II mencapai nilai rata-rata 86 dengan kualifikasi A (Amat baik) yaitu antara 86-100. Dan ketuntasan pembelajaran yang diharapkan mencapai $80 \%$

\section{Hasil Dan Pembahasan}

Hasil Penelitian Pada bagian ini pemaparan data nyang diperoleh di lapangan disampaikan secara rinci. Untuk dapatnya menyampaikan sesuatu dengan baik, perlu terlebih dahulu menyimak pendapat para ahli.

Dalam menyampaikan hasil penelitian dan pembahasan, perlu menyajikan uraian masing-masing siklus dengan data lengkap mulai dari perencanaan, pelaksanaan, pengamatan/observasi dan repleksi yang berisi penjelasan tentang aspek keberhasilan dan kelemahan yang terjadi. Perlu ditambahkan hal yang mendasar, yaitu hasil perencanaan (kemajuan) pada diri siswa, lingkungan, guru, motivasi dan aktivitas belajar. Kemukakan grafik dan tabelhasil analisis data yang menunjukkan perubahanyang terjadi disertai pembahasan secara sistimatis danjelads (Arikunto, Suhardjono, Supardi, 2006:83).

Sesuai pendapat para ahli di atas, maka dalam pemaparan hasil penelitian ini dimulai dengan hasil perencanaan, hasil pelaksanaan, hasil observasi dan hasil refleksi baik yang diperoleh dari kegiatan siklus I maupun kegiatan di siklus II yang didahului dengan deskripsi awal.

1. Deskripsi Awal

Deskripsi yang dapat disampaikan nuntuk perolehan data awal sebagai indikator yang dituntut yaitu minimal guru mampu mencapai ketuntasan belajar dengan nilai sama atau melebihi ketuntasan belum tercapai. Data yang diperoleh hanya 5 guru yang tuntas atau hanya 35,71\% yang tuntas dari 14 guru di SD Negeri 6 Batubulan pada semester II tahun pelajaran 2017/2018 dengan rata-rata 75,14. Data tersebut menunjukkan rendahnya kemampuan guru di SD Negeri 6 Batubulan dalam melaksanakan proses pembelajaran yang inovatif. Kekurangan yang ada adalah akibat proses pembelajaran yang dilakukan oleh guru masih bersifat konvensional. Kelebihannya adalah peneliti sebagai pengawas telah giat melakukan supervisi secara maksimal.

2. Deskripsi Siklus I

Pada siklus I sudah diupayakan untuk perbaikan pembelajaran untuk meningkatkan prestasi dalam melaksanakan proses pembelajaran dengan menggunakan model pembelajaran kooperatif Tipe Team Assissted Individualization (TAI)melalui supervisi klinis selama proses pembelajaran yang inovatif. Peneliti telah giat melakukan kegiatan yang susuai dengan kebenaran teori yang ada sehingga peneliti memperoleh hasil yang lebih baik dari proses awal pembelajaran, yaitu dengan rata-rata nilai 78,85 dari jumlah nilai secara klasikal 1104 dari seluruh guru di SD Negeri 6 Batubulan, dengan prosentase ketuntasan belajarnya adalah $42,85 \%$. Kualifikasi nilai yang diperoleh adalah B (baik) yang ada pada rentang 76 - 
85. Hasil ini belum maksimal, karena belum mecapai indikator keberhasilan penelitian yang mencanangkan dengan minimal prosentase ketuntasan belajar $80 \%$.

3. Deskripsi Siklus II.

Dengan tindakan yang sangat maksimal dan pelaksanaan yang betul-betul mengikuti kebenaran teori sesuai dengan model pembelajaran kooperatif Tipe Team Assissted Individualization (TAl) melalui supervisi klinis dalam melaksanakan proses pembelajaran yang inovatif di SD Negeri 6 Batubulan, dimana hasil yang diperoleh pada siklus II ini ternyata meningkat secara signifikan dengan nilai rata-rata 88,71 dan ketuntasan belajarnya adalah $100 \%$ dengan kualifikasi nilai yang diperoleh adalah $\mathrm{A}$ (amat baik) yang ada pada rentang 86-100.

Model pembelajaran kooperatif Tipe Team Assissted Individualization (TAl)melalui supervisi klinis telah diupayakan maksimal. Kendala yang ada adalah pada diri guru yang berlum terbiasa untuk melaksanakan pembelajaran. Mereka masih berpikir bahwa tugas mereka adalah mengajar dan belum betul-betul dimengerti. Kebiasaan ini masih muncul dan mendominasi pembelajaran pada siklus I. Guru pada siklus I ini masih tetap berdiri di depan kelas memperlihatkan diri pada pengawas bahwa mereka adalah mengajar. Hal ini akhirnya dipecahkan dengan kembali berdiskusi dengan guru-guru, bertanya jawab baik pada saat pertemuan awal maupun pada saat dilakukan pertemuan balikan. Peneliti giat melakukan diskusi, memberi pengertian-pengertian pada mereka dalam upaya menstimulir kegiatan yang dilakukan guru demi adanya perbaikan sesuai arti supervisi. Setelah giat dilakukan upaya untuk perbaikan akhirnya pada siklus I ini nilai guru dapat meningkat walaupun belum sesuai harapan dari usulan keberhasilan penelitian. Dari kemampuan guru awal dengan nilai rata-rata 75,14 dengan ketuntasan hanya mencapai $35,71 \%$, akhirnya pada siklus I ini dapat ditingkatkan menjadi rata-rata 78,85 dengan ketuntasan mencapai 42,85\%.

Upaya yang lebih giat yang bisa peneliti laksanakan pada siklus yang kedua ini berpenekanan pada perbaikan-perbaikan dari kekurangan-kekurangan yang ada pada diri guru. Semua kekurangan pada siklus I yang sudah disampaikan pada refleksi siklus I di depan menjadi acuan bagi peneliti untuk melakukan perbaikan. Perbaikan ini banyak dilakukan pada pertemuan awal sebelum mereka masuk kelas. Pada saat bimbingan tersebut diberi penekanan agar mereka merubah cara yang mereka lakukan selama ini yaitu mengajar dirubah dengan membelajarkan. Jadi guru tidak diharapkan untuk menceramahkan materi, guru tidak diharapkan menghabiskan waktunya untuk berdiri di depan kelas dan berceramah terus menerus mendominasi kelas. Yang dituntut adalah lebih $60 \%$ waktu digunakan oleh siswa untuk memperoleh pengalaman belajar, jadi guru boleh duduk di bangku guru dan tidak harus terus menerus berdiri ngomong ini, ngomong itu sampai habis waktu pembelajaran tetap juga berdiri. Pada pertemuan awal diberikan bimbingan tentang kekurangan-kekurangan yang ada selama siklus I untuk diperbaiki dan diminta agar guru-guru melihat apa yang mereka tulis di RPP dan melaksanakan sesuai apa yang mereka tulis. Disamping itu guru-guru juga diminta untuk memperhatikan waktu sesuai dengan apa yang mereka telah tulis di RPP. Diskusi yang matang yang dilakukan pada pertemuan awal ternyata mampu menghasilkan peningkatan yang cukup signifikan. Dari rata-rata siklus I adalah 78,85 dengan ketuntasan mencapai 78,85\% pada siklus yang ke II naik menjadi 88,71 dengan ketuntasan mencapai 100\%. Keberhasilan ini tidak terlepas dari upaya yang sungguh-sungguh, upaya yang maksimal yang dapat ditujukan untuk peningkatan mutu pendidikan. Rekapitulasi hasil yang dapat disampaikan adalah. 
Tabel 1. Rekapitulasi Hasil Penelitian

\begin{tabular}{|c|c|c|c|c|c|c|c|c|c|}
\hline \multirow[b]{2}{*}{ No. } & \multicolumn{3}{|c|}{ Awal } & \multicolumn{3}{|c|}{ Siklus I } & \multicolumn{3}{|c|}{ Siklus II } \\
\hline & $\begin{array}{c}\text { Per } \\
\text { ole } \\
\text { han } \\
\text { Sko } \\
\text { r }\end{array}$ & $\begin{array}{l}\text { Rata- } \\
\text { Rata }\end{array}$ & $\%$ & $\begin{array}{c}\text { Perole } \\
\text {-han } \\
\text { Skor }\end{array}$ & $\begin{array}{l}\text { Rata- } \\
\text { Rata }\end{array}$ & $\%$ & $\begin{array}{l}\text { Perol } \\
\text { ehan } \\
\text { Skor }\end{array}$ & $\begin{array}{l}\text { Rata- } \\
\text { Rata }\end{array}$ & $\%$ \\
\hline 1 & 40 & 80 & $80 \%$ & 35 & 70 & $70 \%$ & 44 & 88 & $88 \%$ \\
\hline 2 & 31 & 62 & $62 \%$ & 39 & 78 & $78 \%$ & 43 & 86 & $86 \%$ \\
\hline 3 & 35 & 70 & $70 \%$ & 38 & 76 & $76 \%$ & 45 & 90 & $90 \%$ \\
\hline 4 & 34 & 68 & $68 \%$ & 39 & 78 & $78 \%$ & 43 & 86 & $86 \%$ \\
\hline 5 & 46 & 92 & $92 \%$ & 46 & 92 & $92 \%$ & 47 & 94 & $94 \%$ \\
\hline 6 & 40 & 80 & $80 \%$ & 41 & 82 & $82 \%$ & 43 & 86 & $86 \%$ \\
\hline 7 & 46 & 92 & $92 \%$ & 46 & 92 & $92 \%$ & 47 & 94 & $94 \%$ \\
\hline 8 & 38 & 76 & $76 \%$ & 40 & 80 & $80 \%$ & 44 & 88 & $88 \%$ \\
\hline 9 & 34 & 68 & $68 \%$ & 36 & 72 & $72 \%$ & 43 & 86 & $86 \%$ \\
\hline 10 & 38 & 76 & $76 \%$ & 39 & 78 & $78 \%$ & 45 & 90 & $90 \%$ \\
\hline 11 & 37 & 74 & $74 \%$ & 40 & 80 & $80 \%$ & 44 & 88 & $88 \%$ \\
\hline 12 & 33 & 66 & $66 \%$ & 35 & 70 & $70 \%$ & 43 & 86 & $86 \%$ \\
\hline 13 & 40 & 80 & $80 \%$ & 40 & 80 & $80 \%$ & 44 & 88 & $88 \%$ \\
\hline 14 & 34 & 68 & $68 \%$ & 38 & 76 & $76 \%$ & 46 & 92 & $92 \%$ \\
\hline Jumlah & & 1052 & & & 1104 & & & 1242 & \\
\hline Rata-rata & & 75,14 & & & 78,85 & & & 88,71 & \\
\hline Ketuntasan & & $35,71 \%$ & & & $42,85 \%$ & & & $100 \%$ & \\
\hline
\end{tabular}

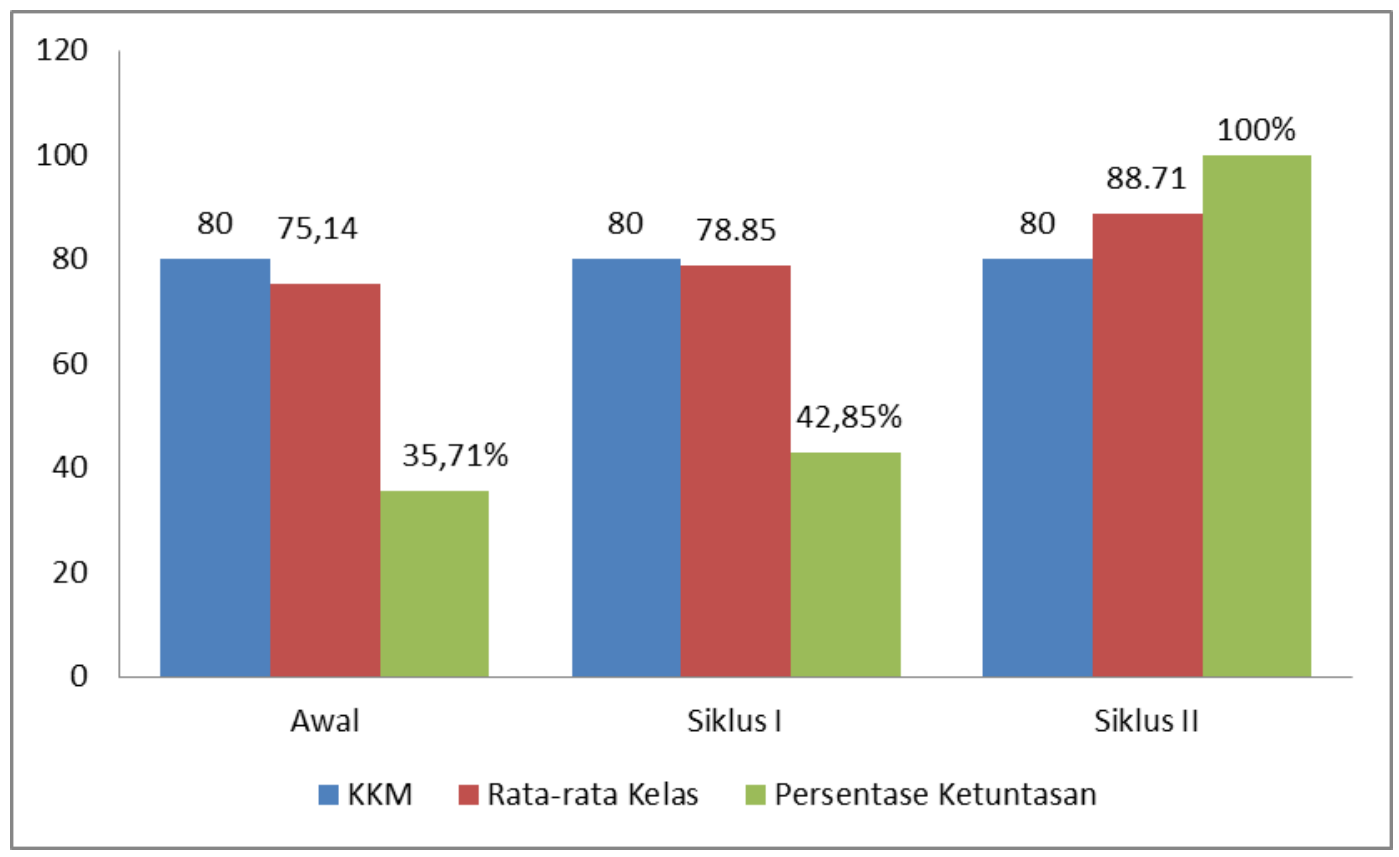

Grafik 1. Rekapitulasi Hasil Penelitian

Hasil penelitian ini sejalan dengan hasil penelitian yang dilakukan oleh Lukman, dkk (2016) yang berjudul Peningkatan Kemampuan Guru Sd Melalui Supervisi Klinis. Hasil penelitiannya menunjukkan bahwa: (1) peningkatan kemampuan guru terasa dalam perencanaan pembelajaran; (2) supervisi klinis berjalan dengan tiga tahap, pertemuan awal, observasi, dan pertemuan balikan; (3) hambatannya adalah belum maksimalnya penggunaan 
media dan pengelolaan kelas dalam proses pembelajaran serta solusinya, guru mesti menggunakan media yang menarik dan mengelola kelas siswa dalam bentuk kelompok kecil.

\section{Simpulan dan Saran}

Penerapan model pembelajaran Kooperatif Tipe Team Assissted Individualization (TAI) melalui supervisi klinis dapat meningkatkan kemampuan guru di SD Negeri 6 Batubulan dalam melaksanakan proses pembelajaran yang inovatif pada semester II tahun pelajaran 2017/2018. Ini didukung dengan bukti-bukti dari hasil analisis data kemampuan awal guru masih cukup rendah, bahnyak hal belum mampu dilaksanakan sudah dibenahi. Pada siklus I sudah terjadi peningkatan yang lebih baik dimana banyak unsur yang mesti dilakukan dalam proses pembelajaran sudah dilakukan. Pada akhir siklus II bahkan kemampuan guru-guru sudah cukup baik. Hal-hal yang belum dilakukan dalam pelaksanaan proses pembelajaran sebelumnya sudah dilakukan dan terjadi kenaikan nilai yang diharapkan.

Analisis secara kuantitatif sudah membuktikan bahwa penerapan model pembelajaran Kooperatif Tipe Team Assissted Individualization (TAl)melalui supervisi klinis dapat meningkatkan kemampuan guru di SD Negeri 6 Batubulan dalam melaksanakan proses pembelajaran yang inovatif pada semester II tahun pelajaran 2017/2018. Perolehan skor awal baru mencapai rata-rata 75,14 dengan ketuntasan hanya mencapai 35,71\%, membuktikan bahwa kemampuan guru-guru dalam melakukan proses pembelajaran masih rendah namun pada akhir siklus I setelah langkah-langkah model pembelajaran Kooperatif Tipe Team Assissted Individualization (TAl)dan supervisi klinis mulai dilaksanakan, sudah terjadi peningkatan perolehan skor menjadi 78,85 , bahkan pada akhir siklus II peningkatannya sudah sangat baik dengan perolehan skor 88,71. Bila dilihat persentase keberhasilannya, pada awalnya baru memperoleh $35,71 \%$, setelah siklus I mencapai $42,85 \%$ dan pada akhir siklus II telah memperoleh peningkatan yang tajam dengan perolehan yang menggembirakan yaitu 100 $\%$ dengan kriteria "Amat Baik".

\section{Daftar Rujukan}

Achdiyat, Maman, Fitriya Andriyani. 2016. Hasil Belajar Matematika Ditinjau dari Model Pembelajaran Teams Assisted Individualization (TAI). Jurnal Formatif Vol. 6 No. 3 Hal. 246-255

Tersedia

Pada

https://journal.Ippmunindra.ac.id/index.php/Formatif/article/view/996.

Arikunto Suharsimi, Suhardjono, Supardi.2006. Penelitian Tindakan. Kelas. Jakarta: Bumi Aksara.

Departemen Pendidikan Nasional. 2006. Manajemen Berbasis Sekolah. Jakarta: Depdiknas.

Departemen Pendidikan Nasional. 2009. Kompetensi Supervisi klinis. Jakarta: Dirjen Peningkatan Mutu Pendidik dan Tenaga Kependidikan.

Depdiknas. Departemen Pendidikan Nasional. 2008. Laporan Penelitian Tindakan Sekolah. Jakarta: Depdinas.

Lalu Muhammad. 1996. Supervisi Klinis. Surabaya: Usaha Nasional.

Lukman, dkk. 2016. Peningkatan Kemampuan Guru Sd Melalui Supervisi Klinis. E-Jurnal UM Volume 1 Nomor 12 Desember 2016.

Lutvaidah, Ukti. 2015. Pengaruh Metode dan Pendekatan Pembelajaran terhadap Penguasaan Konsep Matematika. Jurnal Formatif Vol. 5 No. 3 Hal. 279-285. Tersedia ada : https://journal.lppmunindra.ac.id/index.php/Formatif/article/view/653. 
Megawati, Yolanda Dian Nur, Annisa Ratna Sari. 2012. Model Pembelajaran Kooperatif Tipe Team Assisted Individualization (TAI) dalam Meningkatkan Keaktifan Siswa dan Hasil Belajar Akuntansi Siswa Kelas XI IPS 1 SMA Negeri 1 Banjarnegara Tahun Ajaran 2011/2012. Hal. 162-180. Tersedia Pada https://journal.uny.ac.id/index.php/jpakun/article/view/927.

Sukmadinata, Nana Syaodih. 2007. Metode Penelitian Pendidikan. Bandung: Rosdakarya.

Tama, Bayu Jaya. 2017. Perbedaan Hasil Belajar Matematika Melalui Metode Team Assisted Individualization dan Metode Drill. Jurnal SAP Vol. 1 No. 3 Hal. 322-323. Tersedia Pada : https://journal.Ippmunindra.ac.id/index.php/SAP/article/view/1303 